\title{
ENTREVISTA COM CHRISTIAN BROMBERGER
}

Arlei Sander Damo*

Ruben George Oliven **

Ari Pedro Oro***

Cornelia Eckert ${ }^{* * * *}$

Universidade Federal do Rio Grande do Sul - Brasil

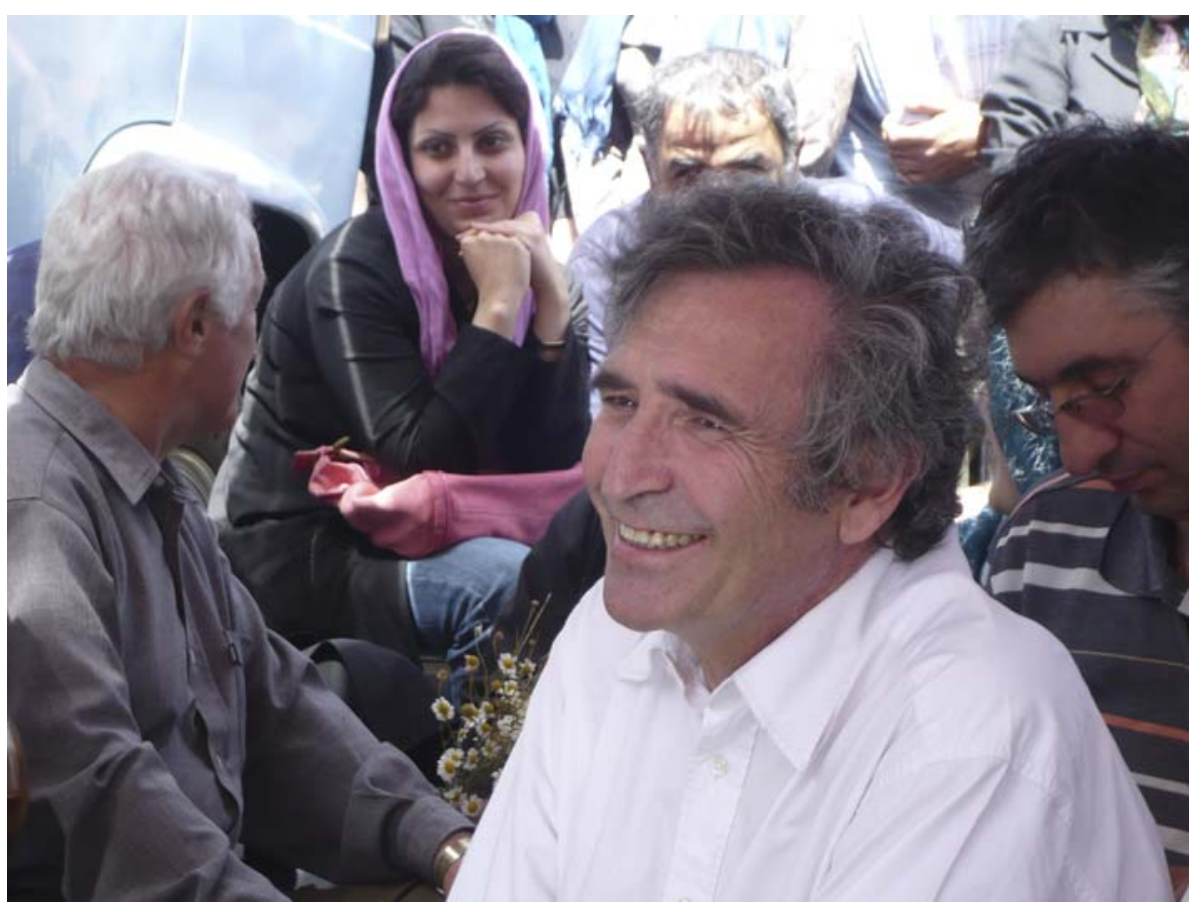

Christian Bromberger (foto: acervo pessoal).

\footnotetext{
* Contato: arleidamo@uol.com.br

** Contato: ruben.oliven@gmail.com

*** Contato: arioro@uol.com.br

**** Contato: chicaeckert@gmail.com
}

Horizontes Antropológicos, Porto Alegre, ano 23, n. 48, p. 351-371, maio/ago. 2017 http://dx.doi.org/10.1590/S0104-71832017000200015 
O antropólogo francês Christian Bromberger esteve em Porto Alegre em meados de novembro de 2015, como convidado do evento "Diálogos Internacionais sobre Esporte, Lazer e Educação Física", realizado na ESEF/ UFRGS. Na ocasião ele também esteve proferindo uma palestra no Instituto Latino-Americano de Estudos Avançados (Ilea/UFRGS), intitulada "Um outro Irã". Esta foi a segunda ocasião em que Bromberger esteve no Brasil, sendo que a primeira delas foi em 2007, por ocasião da realização da VII Reunião de Antropologia do Mercosul. Em 2008, Horizontes Antropológicos aproveitou a organização de um número dedicado à temática esportiva, um dos temas sobre os quais Bromberger tem se dedicado, para publicar um texto inédito de sua autoria. Desta vez realizamos uma entrevista, abordando a trajetória e a obra deste que é tido como um dos maiores especialistas franceses sobre o Irã, tendo, inclusive, dirigido o Instituto Universitário de Pesquisa no Irã. A entrevista foi transcrita por Nadège Mézié, traduzida por L'Atelier des Mots e revisada e editada por Arlei Sander Damo.

\section{Entrevista}

Arlei Sander Damo: Tenho a impressão de que você não é muito conhecido no Brasil, o que não faz justiça à extensão, diversidade e qualidade de sua obra. Então, para começar, sugiro que você fale um pouco de sua trajetória.

Christian Bromberger: Eu comecei fazendo estudos de letras clássicas, latim e grego. Inicialmente, passei num concurso para professor universitário de letras clássicas. Paralelamente, eu havia seguido os cursos de André Leroi-Gourhan, depois de ter passado por um curso de etnologia no Museu do Homem. Ele me havia dito: "Vou te fazer a mesma pergunta que Marcel Mauss me fez quando eu era estudante: 'você vive de rendas?'." Eu não vivia de rendas, então Leroi-Gourhan me disse: "Faça de preferência o concurso para professor universitário; penso que você será etnólogo, mas é melhor estar protegido economicamente." Passei no concurso e depois eu segui os cursos do centro de formação à pesquisa etnológica dirigido por Leroi-Gourhan e por Roger Bastide. Foi aí que encontrei também Jacques Gutwirth, que era um de nossos formadores. Depois disso, fui nomeado para um liceu para ensinar francês, latim e grego no interior, em Orléans. Porém eu retornava regularmente a Paris e tinha previsto de trabalhar na ilha de Socotra, no sul da Arábia 
Saudita. Eu seguia os cursos de sul-arábico de Maxime Rodinson, que era um sábio especializado sobre o Oriente Médio, mas era muito difícil ir à ilha de Socotra. E naquele momento, no Museu do Homem, estava sendo organizada uma equipe para trabalhar no Irã. O persa é uma língua indo-europeia, relativamente próxima das línguas que eu tinha estudado, e a "ocasião faz o ladrão". O acaso tem sempre um papel importante na vida. Há alguns que terminam na Grand-Combe [risos], há outros que, de repente, nos corredores do Museu do Homem, ouvem falar sobre um grupo de pesquisas no Irã. Enfim, por que não o Irã? Então eu fui, em 1971, e lá eu escolhi trabalhar numa província do norte do país. Ao mesmo tempo, fui nomeado professor assistente na universidade de Aix-en-Provence, uma universidade com a qual tive vínculo ao longo de toda a minha carreira.

Em seguida fui designado para o CNRS, o Centro Nacional da Pesquisa Científica, durante dois anos e depois tive a oportunidade de ensinar na Itália, na Suíça e na Argentina, como professor visitante. Também me afastei de Aix temporariamente, mas bem mais tarde, para dirigir o Instituto Universitário de Pesquisa no Irã, onde fiquei três anos de maneira contínua, nos anos 2000. Então o que dizer, além disso? Eu fui, de 1995 a 2005, nomeado no Instituto Universitário da França, que é uma espécie de "pré-Collège de France", cuja grande vantagem era não ter senão um terço das obrigações de ensino e receber financiamento para fazer minhas pesquisas. Isso fez com que eu pudesse ir regularmente ao Irã.

Ari Pedro Oro: Falando de seus mestres, você mencionou Bastide. Você sabe que, para a antropologia brasileira, ele é um ícone. Ele viveu quase 20 anos no Brasil, fazendo pesquisas de campo; ele publicou muito, sobretudo na área das religiões africanas no Brasil. Qual lembrança você tem do Bastide como pessoa, como intelectual? Ele falava do Brasil quando ensinava?

Christian Bromberger: Eu lembro de um curso sobre as classes etárias e as diferenças culturais. Foi um curso que frequentei quando era estudante de etnologia. Ao mesmo tempo, guardo a lembrança de uma pessoa muito calorosa. Nos anos 1970, tínhamos constituído um grupo de pesquisa sobre o Mediterrâneo, e Bastide participava dele. Ele chegava com seus charutos [risos]... Ele era de Anduze, uma pequena cidade de Cévennes, onde nós fomos fazer um estágio com os estudantes. Ele nos dizia: "Vocês compreendem, eu 
fui fazer meus estudos em Paris e lá as pessoas nos convidavam para as suas casas, mas comíamos na cozinha, assim mesmo, sem preparação, enquanto que em Anduze, no mundo mediterrâneo, quando se recebe alguém, ah!, é preciso começar a preparar um dia antes, ir fazer as compras, usar os estoques de comida." E ele tinha ficado muito impressionado, como jovem estudante que chega a Paris, pelos hábitos culturais diferentes em matéria de hospitalidade. Então sim, ele era tão cultivado e caloroso que tínhamos muito prazer em estar com ele. Isso foi alguns anos apenas antes de sua morte. E eu me lembro de ter escrito um artigo em homenagem a Roger Bastide, precisamente sobre o pequeno povoado de Cévennes.

Ruben George Oliven: Na sua escolha pelos clássicos e depois pela etnologia, você teve uma influência da casa, da família?

Christian Bromberger: Não. Eu tive, sobretudo uma influência negativa. Eu pensei "eu não vou passar minha vida estudando textos clássicos". Eu achava muito bonita a poesia de Píndaro, de Virgílio, mas eu pensava, eu prefiro estudar pessoas em vez de livros. Por outro lado havia Leroi-Gourhan. Ele não era um bom orador, mas quando eu comecei a fazer seus cursos, eu pensava "ora, isso me interessa! Eu tenho vontade de fazer isso" em vez de ir traduzir Virgílio ou Píndaro, mesmo que seja muito bonito.

Ruben George Oliven: E sua família, era uma família onde havia um ambiente intelectual?

Christian Bromberger: Mais ou menos. Foi uma escolha pessoal. A atmosfera familiar não pesou sobre isso.

Ari Pedro Oro: E Lévi-Strauss, teve alguma influência em sua carreira?

Christian Bromberger: Lévi-Strauss, eu não o tinha conhecido durante meus estudos. O que aconteceu, visto que estamos falando de coisas pessoais, é que tinha escrito um pequeno artigo, em 1976, sobre os nomes próprios de um vilarejo do sul da França, e o enviei para Lévi-Strauss. Vocês sabem, quando se é jovem, ousa-se tudo [risos]! Ele me respondeu: "Você fez um artigo extraordinário." Então quando você tem 25 anos e alguém como Lévi-Strauss 
diz isso... Começamos a nos corresponder e eu o encontrei algumas vezes, mas sobretudo nos escrevíamos. Então, há temas que o interessavam mais ou menos. Por exemplo, sobre futebol, ele nunca respondeu [risos].

Arlei Sander Damo: Eu imagino, ele não gostava nem mesmo de jazz...

Christian Bromberger: Exatamente... Em todo o caso, fui muito influenciado pelo La pensée sauvage ${ }^{1}$ pelo Le totémisme aujourd'hui, ${ }^{2}$ que eu achei obras notáveis. De outra parte, Leroi-Gourhan me influenciou muito sobre a importância do trabalho empírico, embora ele próprio não tenha feito etnologia. Fui relativamente apaixonado pelas obras do estruturalismo de Lévi-Strauss, sobretudo aquelas que colocavam em causa Lévy-Bruhl e que o haviam precedido nas questões sobre "mentalidade primitiva". Isso me interessou muito.

É preciso também dizer que o ambiente junto de Lévi-Strauss e LeroiGourhan não era o mesmo. O ambiente de Leroi-Gourhan era relativamente familiar, rústico, tomava-se vinho tinto. No caso de Lévi-Strauss, era muito mais intelectual, e seguia as tendências. Logo, de intelectuais que bebiam de preferência uísque [risos]. Eram dois mundos diferentes, socialmente e intelectualmente.

Arlei Sander Damo: Você falou um pouco do Irã, mas o que o levou ao futebol?

Christian Bromberger: Retornei do Irã em 1982, em plena guerra IrãIraque, era um período de repressão. Eu me interessava pela cartografia etnológica, em fazer estudos sobre as técnicas extremamente rigorosas sem levar muito em conta os temas, os indivíduos. Eu me interessava, como falei há pouco, por Cévennes, no sul da França. Se estudamos o que interessa aos etnólogos, por que não estudar aquilo que interessa às pessoas? As velhas tradições na França do sul são interessantes, os velhos sistemas de parentesco, mas não é isso que apaixona as pessoas e, a partir daquele momento, eu pensei

Lévi-Strauss (1962a).

Lévi-Strauss (1962b). 
que era preciso também estudar os temas que fazem vibrar as pessoas, pelos quais elas se apaixonam, pelos quais elas têm interesse, gritam, brigam, etc.

Ruben George Oliven: É isso que você chama de paixões ordinárias...

Christian Bromberger: É isso. São paixões que não chegam a ser reconhecidas como paixões numa sociedade. Paixões ordinárias porque são paixões socialmente admitidas. Fazer artesanato é permitido; amar o futebol é permitido. Bom, depois, há paixões, não sei, pornográficas, isso não é abertamente admitido. Logo, as paixões ordinárias, para mim, são paixões que são socialmente permitidas. E então, entre aquelas permitidas, de fato, está o futebol. Naquele momento, retornando do Irã, fui ver jogos de futebol, o que eu não tinha feito desde muito tempo, e vendo o que estava acontecendo, eu pensei "por que não estudar isso em vez do rito da Virgem Maria, nos Alpes, à procura de velhos de barba branca que me contarão como isso aconteceu 50 anos atrás?". Isso não quer dizer que eu recuse os temas mais convencionais, mas levar em conta as paixões e a maneira pela qual isso revela alguma coisa de uma sociedade, e não simplesmente para descrever a paixão das pessoas, mas para ver o que isso significa, como isso funciona e o que isso quer dizer, é isso que me interessa.

Arlei Sander Damo: A propósito, contribuições como a sua ajudaram a mudar o status da temática esportiva nas ciências sociais, mas não mudou tanto, não? Ainda é um tema secundário, colocado de lado. Por quê?

Christian Bromberger: Porque há uma falta de legitimidade do assunto, que está ligada, sobretudo, ao fato de que os intelectuais, ao menos na Europa, se interessaram muito pouco por esse tema, como atores e não tanto como especialistas. Vocês sabem, fala-se do futebol como ópio do povo, como alguma coisa cheia de vulgaridade onde haveria ao mesmo tempo histórias de corrupção, etc. É verdade que há histórias de corrupção no futebol, mas este não era um tema digno de interesse como podiam ser as peregrinações, os partidos políticos ou a classe operária, etc. [...] Os jogos, e sobretudo os jogos populares, espetáculos onde as pessoas dizem palavrões, não é a classe operária tal como se sonhou, aquela que deve fazer reivindicações políticas. Logo, é um tema muito pouco legítimo. E, para dizer a verdade, felizmente eu não comecei a trabalhar sobre isso porque teria tido uma carreira muito mais difícil [risos]. 
Ora, para mim me parece que, frequentemente, uma sociedade revela o essencial dela mesma através dessas margens ou daquilo que é considerado como margens. Falava-se das paixões ordinárias e a do futebol, em particular, porque é o tipo de tema onde todo mundo tem alguma coisa a dizer, o que é muito confortável quando você estuda o Gilan, que além de mim e de duas ou três pessoas no mundo, ninguém conhece [risos]. Ninguém vai me dizer que não é assim. Enquanto que todo mundo pensa alguma coisa do futebol. É mais delicado e, ao mesmo tempo, ninguém acredita realmente no seu aspecto revelador.

Ari Pedro Oro: Você fez uma aproximação entre pelos e religião, e futebol e religião também... Nesse campo há um problema teórico, há a religiosidade, há, por exemplo, o que podemos nomear a religião secular, que pode estar presente na medicina, na ciência, nas ideologias políticas, etc., de grandes acontecimentos e o futebol também como religião da maioria, etc. Há aqueles que falam de reencantamento do mundo através da religião; em qual área você se situa?

Christian Bromberger: Já estive num debate em que alguém utilizava a noção de ritual a toda hora. Pessoalmente, eu sou muito reservado quando a isso, em meu livro Le match de football ${ }^{3}$ há um capítulo sobre o futebol como ritual, com o argumento de que podemos caracterizar essas grandes reuniões como rituais. Todavia, são rituais sem exegese. Não é como um ritual convencional, como a missa, onde se sabe o que significa o fato de tomar a hóstia. Em todo o caso, há de fato uma série de elementos rituais tais como: a repetição, a reunião, o fervor, mas não há nada que nos diga de onde nós viemos e aonde nós vamos, como podem dizer-nos as religiões. E por isso eu desconfio da extensão e de uma banalização do conceito de ritual. Para o futebol, eu cheguei a essa noção de ritual sem exegese, sem promessa de futuro, sem mensagem sobre a origem, etc., com toda uma série de atributos do ritual que vêm provavelmente da religião ela mesma, como o fato de se levantar em alguns momentos da partida, como o fato de que há superstições nos vestiários.

3 Bromberger (1995). 
Ari Pedro Oro: Os ídolos...

Christian Bromberger: Sim, os ídolos! Estive nos vestiários dos jogadores de futebol no Irã, onde se passa embaixo do Corão antes de entrar no gramado. $\mathrm{O}$ goleiro tem versos do Corão em suas luvas. Mas não se pode dizer, no entanto, que se trata de um ritual religioso. Eu acredito que seria um excesso dizer isso. Bem, religião secular, eu aceito sim, mas enfim, vocês veem, nesse sentido eu sou relativamente reservado tendo em vista os risco desses usos conceituais demasiadamente alargados. O que me interessa nos fenômenos em relação a esses grandes conceitos é saber o que os diferenciam em vez do que os assemelham. E é sobretudo isso que é interessante; é ver a diferença específica em vez da convergência genérica.

Ruben George Oliven: Você acredita que há uma espécie de "obesidade conceitual" nas ciências sociais hoje? No sentido de que tudo pode entrar num conceito.

Christian Bromberger: Sim, talvez, o conceito de ritual é muito evasivo. Vi há poucos dias um jovem pesquisador que fazia uma exposição interessante, ele falava de pessoas que se reuniam num parque público e que comiam juntas, então era um ritual! É uma refeição, há comensalidade, há sociabilidade, mas onde está a transcendência? O que distinguiria o rito de um ritual precisamente? Talvez Goffman pudesse nos ajudar a evitar certos excessos interpretativos.

Arlei Sander Damo: Seu interesse pelo futebol corresponde também a um momento onde o Irã havia mudado, com a deposição do regime do xá, e o trabalho de campo se tornara complicado, como vinha dizendo...

Christian Bromberger: Em 1982 eu retornei ao Irã, e não sem dificuldades. Depois, eu não retornei mais até 1991. Durante esse período, havia de fato com o que ocupar o tempo. Vocês sabem que ir a campo é sempre um problema, porque eu não gosto muito de ser convidado... Sobretudo quando se trabalha no Oriente Médio ou sobre campos sensíveis, a categoria de "convidado" é delicada. Ontem, eu via, eu creio que era Tariq Ramadan, que estava em Doha, no Qatar, eu não gostaria de ser convidado 
para ir ao Qatar, se me convidam eu não irei! E para ir ao Irã entre 1982 e 1991, o que era preciso fazer? Era preciso estar de acordo com o regime, tudo isso. A partir de 1989, houve um novo presidente da República que era Rafsandjani, e as coisas mudaram um pouco. Não precisava mais obrigatoriamente se mostrar conivente com o regime. Fazer etnologia no Irã não é abertamente permitido porque se pensa sempre que somos espiões. Não se acredita que vamos fazer etnologia, que vamos estudar uma família no norte do Irã: "Não, não, não, não, este senhor está aqui para outra coisa, ele não vai colocar os pés na lama para simplesmente ir saber com quem se casa e como se reza, etc., não, não, não, não, não é verdade." Há outra coisa por trás de tudo isso. Com a mudança de regime houve uma mudança de perspectiva, não se podia mais circular no Irã como antes. Eu frequentei uma família e é essa família que constituiu um pouco daquilo que vocês puderam ver no livro que eu lancei, Un autre Iran, ${ }^{4}$ que fala muito de uma família e de seu funcionamento. Com essa ideia de ser mais cuidadoso que antes naquilo com o que pensam as pessoas elas mesmas e não simplesmente com aquilo que eu penso que elas pensam.

Arlei Sander Damo: Mais recentemente você se interessou por alguma coisa muito particular, eu penso, que é a pilosidade. Como chegou a isso?

Christian Bromberger: Tanto no futebol quanto no Irã, o pelo tem uma importância muito particular. No futebol, todos os jogadores têm penteados muito particulares e a evolução do penteado foi extraordinária em 40 anos. Antes eles tinham os cabelos curtos, com as orelhas bem à mostra. Depois houve a copa dos jogadores de futebol com os cabelos longos atrás e curtos em cima. Depois, teve as tranças dos jogadores africanos, mas também dos jogadores japoneses, com tranças loiras às vezes. E depois, temos o undercut recente. Enfim, isso me levou a perguntar: quais são as pessoas que mudam de penteado com frequência e o que isso quer dizer?

Já no Irã, há uma relação interessante entre o véu e o fato de que as meninas, na véspera do casamento, depilam as sobrancelhas e também o corpo completamente. E as depiladoras têm muito trabalho, porque o Irã é um país

4 Bromberger (2013). 
onde as pessoas são muito peludas. Vejam a barba dos mulás, é um atributo importante. Logo há toda essa ligação entre pelos e religião. E o que tinha me interessado muito é a diferença na relação do sagrado entre os mulás, por exemplo, que têm uma barba regular e os místicos, os dervixes ou os eremitas, inclusive em nossas sociedades, que têm barbas muito mais rústicas. Tem ainda a relação entre o pelo e a política... Tudo isso fez com que eu pensasse "mas enfim, é preciso trabalhar sobre a pilosidade!".

Arlei Sander Damo: É um tema transversal, como o futebol, que perpassa as classes, as religiões, as fronteiras nacionais, de gênero, etc. É muito interessante como você fala da experiência de mulheres que perderam seus cabelos por causa do câncer...

Christian Bromberger: Mesmo que a pesquisa no Irã não tenha sido fácil, a pesquisa junto às mulheres que perderam seus cabelos foi um dos campos mais exigentes que eu conheci. Não era preciso um uísque, mas dois, depois desses dias passados no hospital de Marselha. E, de fato, lá eu me dei conta de muitas coisas em relação à importância dos cabelos e dos pelos corporais também, aliás, sobretudo para as mulheres, mais que os homens, a partir dessas constatações. Um personagem que me interessou muito foi a cabeleireira do hospital, como ela procedia para cortar os cabelos [...]. Também me chamou a atenção a maneira como às vezes as mulheres se sentiam amputadas por perder os cabelos, tanto quanto perder um seio. Porque são dois símbolos fortes da feminilidade. Por outro lado, o que me chocou muito era o retorno ao cabeleireiro. Quando as mulheres estão curadas e elas não vão mais ao cabeleireiro do hospital, mas no verdadeiro cabeleireiro, que pode pintar o cabelo e fazer um monte de manipulações que são proibidas quando elas estão no hospital; naquele momento, recupera-se o sentimento de ser novamente uma mulher, no sentido pleno do termo.

Arlei Sander Damo: Podemos retornar novamente ao Irã? Você atravessou mudanças radicais do ponto de vista político e econômico. O que você pode dizer sobre a cultura do Gilan e do Irã?

Christian Bromberger: O Gilan é uma província muito particular. Lá o estatuto dos homens e das mulheres não é o mesmo que no planalto 
iraniano; há uma mistura de folclore tradicional, de religião popular com religião oficial; há também estruturas de parentesco que não são aquelas que encontramos, por exemplo, nas sociedades tribais; o que me chama a atenção no Irã em geral, e nas classes médias ao menos no Gilan, é esta mistura hoje de cultura islâmica e por outro lado, de cultura ocidental. É alguma coisa sem dúvida relativamente geral em muitas sociedades, mas os iranianos vivem sob o modelo de um duplo eu. Há o "eu" oficial, nas ruas, nas administrações públicas, nas universidades, onde é preciso seguir a ordem estabelecida. E depois, há a casa, lá frequentemente há fitas cassetes ocidentais, há filmes que vêm da América e que se conhecem mais rapidamente no Irã do que na França. Porque há uma circulação que é extremamente rápida. Logo, há ali um contraste muito forte entre o exterior e o interior, que se inverteu desde o regime do xá. No tempo do xá, ia-se ao exterior para fazer o ocidental: beber álcool, dançar, escutar música ocidental. No interior, olhava-se diretamente nos olhos do seu interlocutor, falava-se das coisas graves da vida [risos]. Mas isso foi invertido e, psicologicamente, é difícil. Difícil de ter duas vidas. Uma no interior, uma no exterior. Frequentemente, não se consegue sair disso.

Eu tinha convidado alguns amigos que eram de origem campesina iraniana à Aix-en-Provence, quando eu retornei do Irã. Eles chegaram e um rapaz me disse: "Eu, aqui na França, vou viver como os franceses." Logo ele começou a beber o aperitivo, etc. Depois ele foi à Paris e, de repente, teve um sonho. O sonho no Irã é muito importante! No sonho ele viu uns bassidji - os bassidji são os voluntários da Revolução - que chegavam com chicotes. E, de repente, lhe apareceu o meio-irmão do imã Hussein, que é o imã venerado pelos xiitas, e ele lhe disse: "Não, não, não se deve continuar a viver assim, como tu fazes." Ele retornou à Aix e me disse: "Não, não, agora vou parar de beber, vou fazer minhas orações." Logo, ele tinha sido recuperado por sua tradição.

Ruben George Oliven: No inconsciente...

Christian Bromberger: Sim, há sempre essa tensão que é psicologicamente muito difícil. Então, claro que isso não vale para todo mundo. Há pessoas que estão de acordo com a ética do poder político tanto no interior quanto no exterior, etc. Mas é alguma coisa que existe no Irã. O Irã é um país 
muito culto, enfim, muito alfabetizado ao menos, e há antenas parabólicas que são proibidas, mas dá-se um jeito sempre de ter uma que capta programas dos iranianos de Los Angeles que se chama Teherangeles. Então dizem assim: "Escuta, esta noite, eu vou ver mulheres nuas!" Mas o que é isso [risos]? De fato, são mulheres usando mangas curtas [risos]!

Ruben George Oliven: $\mathrm{O}$ que o Irã pode nos ensinar em relação às teorias que foram desenvolvidas na Europa e nos Estados Unidos sobre a modernização e a secularização? Porque é um país, num sentido, muito moderno, há pessoas cultas, eles têm tecnologia atômica, as mulheres estão no mercado de trabalho, tudo isso; e ao mesmo tempo, é uma teocracia onde a religião tem um papel muito importante. Então, é outra modernidade, me parece. O que podemos pensar desse modelo?

Christian Bromberger: Nós seguidamente nos enganamos sobre o Irã. A maior historiadora do Irã, Nikki Keddie, dizia, ainda em 1977, que o Irã iria se tornar um país leigo com uma modernização crescente. Ninguém previu a revolução iraniana de 1978. Depois da revolução, há pessoas que disseram: “Ah, sim, eu tinha previsto!" Mas enfim, eles tinham escrito com tinta invisível, talvez [risos]. Logo, todo mundo foi surpreendido com isso.

Ruben George Oliven: Você também?

Christian Bromberger: Eu também. O que é verdade nesse processo é que... eu falava há pouco do duplo jogo. Mas esse duplo jogo, ele é sincero, isso faz com que o mesmo indivíduo possa olhar esses filmes ocidentais, mas, durante os períodos rituais onde se comemora o martírio do imã Hussein, ser extremamente apegado aos valores de sua cultura. E assim, não se podem dissociar as duas partes. O que me chama a atenção, dependendo das horas do dia, dependendo dos dias da semana, dependendo dos meses do ano, pode-se ter essa reafirmação. Mesmo essas meninas que deixam escapar mechas loiras de seus lenços, etc.: há semanas rituais, vocês podem estar certos que elas estarão lá se lamentando, chorando sobre o martírio do imã Hussein. Assim, é verdade que a modernização não combina obrigatoriamente com a laicização. E ao mesmo tempo o Irã é um país muito moderno. As mulheres dirigem, há mais mulheres que homens na universidade. 


\section{Ruben George Oliven: Como estudantes?}

Christian Bromberger: Como estudantes. É verdade que não se tem acesso à profissão no Irã por meio dos estudos. Vai-se fazer os estudos e depois, se for um homem, segue-se a profissão de seu pai, se ele é comerciante, por exemplo, e se for uma mulher, bem, nesse momento, talvez... Mas há mesmo assim um emprego feminino, sobretudo no caso dos funcionários públicos, o que não é negligenciável. Mesmo se isso é objeto de tensões evidentemente na sociedade iraniana.

Arlei Sander Damo: O Irã é uma coisa e o "mundo arábico" é outra, mas no Ocidente - e no Brasil, sobretudo - há confusão a respeito. Durante os eventos que ficaram conhecidos como a Primavera Árabe, em 2011, houve muita euforia com a possibilidade de democratização, de laicização, enfim, de ruptura. $\mathrm{O}$ que você pensa que resta disso e como os iranianos viram tais manifestações?

Christian Bromberger: É verdade que houve esse movimento de reivindicação democrática, conhecido como Primavera Árabe. Mas é somente na Tunísia que esse movimento teve continuidade. Quando se vê o que se passa no Egito... Houve a Primavera Árabe, mas lá há uma nova ditadura árabe.

Quanto aos iranianos, eles dizem que fizeram a sua Primavera em 2009, quando houve aquelas eleições fraudadas para a reeleição de Ahmadinejad. Naquele momento houve um levante de uma parte da população, da juventude urbana em particular. De maneira geral, os iranianos não suportam os árabes. É preciso saber disso: são inimigos. Historicamente, os árabes são conquistadores. O discurso sobre os árabes no Irã é pior do que podemos ter nos países ocidentais. Não se pode compreender o Irã sem levar em conta que os iranianos se consideram a primeira potência no mundo. O que historicamente não é inteiramente falso, porque é um país muito antigo. Os árabes são considerados invasores; os russos são os selvagens no Norte; os americanos são uns idiotas, porque são manipulados pelos ingleses [risos]. Há, no máximo, os franceses e os italianos - bom, haveria provavelmente os brasileiros também, que estariam um pouquinho fora do grupo [risos]. Eu me lembro de ter feito um seminário em Teerã sobre culinária. A culinária só pode ser a iraniana; os árabes só devem comer coisas cruas [risos]. E não eram camponeses que me diziam isso! 
O Irã é um dos raros países onde nem sempre o resultado das eleições está assegurado. Quando houve a primeira eleição de Ahmadinejad, todo mundo pensava que seria Rafsandjani que seria eleito, mas não foi o caso então. É muito estranho o sistema político iraniano. Vocês veem o guia, por exemplo, que é um personagem importante. É preciso ver que Ahmadinejad, Rohani, os presidentes da República, não são grande coisa. É um pouco como um primeiro ministro para nós. O homem que dirige as coisas é o guia. Esse guia é nomeado por um comitê, eleito pela população. Logo, trata-se de um governo democrático, dizem os iranianos. Um sistema religioso, com um guia, que pode operar com a democracia. Eu não acredito nisso completamente, porque se o guia e o povo não estão de acordo, não vai ser a saída democrática que vai ganhar, mas o guia. É ele quem tem, segundo a constituição, a legitimidade absoluta.

Ari Pedro Oro: E o papel político da juventude em tudo isso?

Christian Bromberger: É sobre ela que repousam as esperanças de democratização. Mas ao mesmo tempo, é também ela que é reprimida com mais facilidade. Isso é verdade notadamente para o Egito, com todos os tipos de governo, seja aquele da Irmandade Muçulmana, seja o governo militar atual. No Irã, foi muito importante esse movimento da juventude. É uma juventude escolarizada, uma juventude que sabe o que acontece no exterior. Vejam, o Irã nunca foi um país fechado, como foi o Camboja, a Coreia do Norte ou os antigos países soviéticos. Era preciso esperar para ter uma passagem de avião para ir à Los Angeles, mas no final dos encaminhamentos podia-se ir.

Arlei Sander Damo: Você também se interessou pela trajetória de Germaine Tillon. Poderia nos falar um pouco mais a respeito?

Christian Bromberger: Germaine Tillon acaba de entrar no Panthéon. Com um amigo, Tzvetan Todorov, criamos uma associação, Germaine Tillon, que foi uma mulher extraordinária, tendo feito trabalho de campo na Argélia e nos Aurès, de 1934 a 1940. Uma mulher ir a campo sozinha, naquela época, nas montanhas berberes da Argélia, não era frequente. Depois ela retornou à França, em 1940, e rejeitou imediatamente o armistício e contribuiu para criar a rede do Museu do Homem, que foi uma rede de resistência. Ela foi 
denunciada, colocada na prisão e levada à Ravensbrück, durante 18 meses, de 1943 a 1945. Em Ravensbrück, ela encontra Margaret Buber-Neumann, que lhe conta o que acontece do lado de Stalin. Após a guerra, ela cria, com um outro personagem, David Rousset, uma associação de luta contra o autoritarismo, de todos os tipos, sejam nazistas ou stalinistas. Depois ela escreve um livro sobre Ravensbrück, que é uma etnologia de Ravensbrück, cuja descrição é extremamente precisa: todos os blocos, como se comportavam os guardas, a SS, etc. É de uma precisão notável. Depois ela escreve também um grande livro de etnologia, segundo minha opinião, que é Le harem et les cousins, ${ }^{5}$ sobre a condição das mulheres no mundo mediterrâneo. $O$ título não é muito feliz; foi escolhido por Jean Lacouture, editor da Éditions du Seuil, porque Le harem et les cousins parece um livro sobre os árabes estigmatizando as mulheres. Na verdade, seu livro aborda a totalidade do Mediterrâneo, não somente sobre o mundo árabe ou muçulmano. Em 1999, aos 92 anos (ela morreu aos 101 anos), começou a escrever um livro sobre suas observações e suas análises na Argélia, dos anos 1934 a 1940, um livro que se chama Il était une fois l'ethnographie. ${ }^{6}$ Ela é alguém que, ao mesmo tempo, em 1996, participou, com Edgar Morin e com duas outras pessoas, de um movimento de ajuda a refugiados, pessoas que estavam na França e não tinham documentos. Foi alguém que conciliou a verdade e a justiça. Tínhamos, com a associação que fundamos, militado muito para que ela entrasse no Panthéon, para que uma mulher estivesse no Panthéon. Com outra que entrou no Panthéon naquele momento, é isso.

Ruben George Oliven: E Madame Curie?

Christian Bromberger: Sim, sim, Madame Curie. Marie Curie, sim. É a segunda mulher a entrar no Panthéon. Com Geneviève de Gaulle-Anthonioz que também esteve em Ravensbrück, mas ela não fez etnologia, ela fundou a associação Ajuda a Todas as Misérias (ATD Quarto Mundo), que trabalha com os pobres, os miseráveis na França. Germaine Tillon, é alguém que, diferentemente de Lévi-Strauss, faz etnologia perto das pessoas.

Tillion (1966).

6 Tillion (2000). 
Arlei Sander Damo: Ela deixou uma herança intelectual na antropologia francesa?

Christian Bromberger: Muito pouco, porque, para dizer a verdade, suas amizades são sobretudo de Ravensbrück. Ela foi diretora de estudos na École des Hautes Études, mas manifestadamente não é lá que ela tem filiações. Então, ela formou um bom número de alunos, há um bom número de pessoas que fizeram sua tese com ela. Mas não se pode dizer que ela criou uma espécie de escola. E ela ainda é mais conhecida como resistente do que como etnóloga. Mas, segundo minha opinião, Le harem et les cousins é um grande livro. Porque ele mostra bem o estatuto das mulheres no mundo mediterrâneo. Ela analisa a situação no mundo mediterrâneo, mas não é alguém que assinasse petições. Aliás, ela não protestava nos jornais; preferia as ações concretas aos grandes discursos ideológicos.

Arlei Sander Damo: Isso se parece com Mauss? Porque ele também escrevia sobre sociologia e ao mesmo tempo textos socialistas...

Christian Bromberger: Sim. Germaine Tillon foi aluna de Mauss. Ela tinha preparado sua tese com Mauss. Essa tese desapareceu em Ravensbrück. Ela a tinha levado porque, vocês sabem, as pessoas the haviam dito "você vai ser internada", mas você não sabe em quais condições. Logo em seguida, ela recapitulou aquilo que ela se lembrava de suas pesquisas neste livro Il était une fois l'ethnographie, que foi redigido em 1999 e publicado em 2000. Por isso, sim, o sistema de Germaine Tillon é pesquisar, compreender, intervir. É isso. Mas, em nenhum caso fazer uma petição ou um manifesto geral se não se pesquisou e se não se compreendeu. Isso faz com que estejamos muito longe da assinante profissional de petições, vocês sabem que temos isso nos intelectuais na França, com frequência, assinam-se coisas sobre temas que não conhecem. Nesse caso dela, não!

Ruben George Oliven: Seu interesse e o interesse de Tzvetan Todorov...

Christian Bromberger: Então, eu descobri Germaine Tillon pelo Mediterrâneo; Tzvetan, ele a descobriu pela resistência. Depois, eu fui muito impressionado por Ravensbrück porque era quase uma das primeiras obras de 
etnologia sobre outra coisa que não os índios, os africanos, os berberes, os iranianos, etc. Era realmente etnologia da contemporaneidade ocidental. Eu sei que Miriam Grossi também é fã de Germaine Tillon, tendo feito um filme ela. Eu também a filmei, em 2001, ela tinha, naquele momento, 94 anos.

Arlei Sander Damo: Na antropologia brasileira, mas também na antropologia sul-americana, há uma tendência pós-colonialista que critica a antropologia clássica, que coloca em paralelo a dominação política e econômica com a pesquisa científica e a antropológica em particular. Você dirigiu o Idemec, que é um centro que reúne etnólogos que trabalham nos países do Mediterrâneo, nos Bálcãs, no Magreb, no Leste Europeu, etc. Como os pesquisadores do Idemec se situam em relação a essas questões do pós-colonialismo?

Christian Bromberger: É verdade que a antropologia foi criada pelos Estados coloniais para conhecer as sociedades que estavam sob seu domínio. Bom, houve mesmo assim, antes que eu fale dos estudos pós-coloniais, muitas reformas no interior mesmo da etnologia para bem captar a situação das populações que se estudava e não ter esse olhar dominador sobre essas populações. Foi o mesmo caso sobre o Mediterrâneo; houve o olhar anglófono sobre o mundo mediterrâneo, com bons trabalhos, aliás. Mas é verdade que as etnologias nativas dos Bálcãs, da Argélia, do Marrocos, etc., não foram levadas em conta e que o mainstream era essa antropologia anglo-saxônica, que tinha uma espécie de exclusividade bibliográfica sobre o mundo mediterrâneo. Penso que houve bons trabalhos etnológicos feito por italianos, mas acabaram sendo pouco lidos em relação ao mainstream anglófono. Houve nesse laboratório, o Idemec, não uma revolta contra esses grandes mestres, porque havia coisas extremamente interessantes, mas a vontade também de levar em conta outras correntes que simplesmente o mainstream. [...] Para a Europa mediterrânea, houve também essa tendência a ser dominado, não colonialmente, mas intelectualmente pelas grandes correntes da antropologia inglesa e depois americana. Então houve essa rebelião dos assuntos etnológicos, dizendo: "Nós temos algo a dizer sobre nossas sociedades!" Dito isso, posso afirmar que não estou pessoalmente convencido por um modelo de antropologia onde seria suficiente estender um microfone e perguntar às pessoas o que elas pensam da situação. Eu acredito que assim perderíamos a nossa especificidade. Eu sei que houve abusos no outro sentido e que não é somente o etnólogo que 
tem coisas a dizer. Mas, por outro lado, se nosso papel é somente o de gravar as afirmações dos outros, isso não me parece corresponder à vocação de uma disciplina. Uma disciplina de ciências sociais deve procurar ir além da simples formulação das pessoas. Isso não é traí-las, não é deixar de levá-las a sério, não é desprezá-las.

\section{Cornelia Eckert: Sobre a antropologia francesa?}

Christian Bromberger: Sobre a antropologia francesa, bom, ela está muito dispersa hoje. Nós tínhamos grandes modelos que eram o estruturalismo, o marxismo, etc. Hoje, ninguém mais ou quase ninguém reivindica esses modelos. Por isso as pessoas fazem como podem, cada uma por seu lado. Há evidentemente um movimento que toma força, que é este movimento que estabelece uma espécie de igualdade entre humanos e não humanos. Ora, posso compreender, do ponto de vista metodológico, que se faça um não humanismo metodológico, isto é, bom, se realmente as pessoas pensam que Deus existe ou que os objetos falam, é preciso levar em conta metodologicamente isso, é claro, para restituir a experiência deles. Mas passar disso a uma ontologia onde se reconheceria o mesmo estatuto e um estatuto de agente mesmo aos objetos, por exemplo, vamos tomar os objetos ou os animais ou não sei o quê. Eu sei que essa tendência é muito forte hoje. Mas, pessoalmente, eu desconfio muito disso. Eu creio que não se pode praticar um relativismo absoluto. Eu sei que nesse campo eu não farei somente amigos.

Ruben George Oliven: Então para você a antropologia tem em vista sempre a interpretação?

Christian Bromberger: Interpretamos, bem ou mal, e depois podemos criticar o que interpretamos. O que as contribuições recentes sugeriram, e com razão, é de levar mais ainda em conta o ator. O fato de que ele não é simplesmente um agente manipulado, mas que ele dispõe de uma possibilidade de ação que lhe é própria. Mas eu não concordo em eliminar toda a base social e cultural de suas ações. A antropologia não é uma ciência dos indivíduos. Se for isso, não me interessa. Se for uma espécie de psicologia, a antropologia estará completamente dissolvida [...]. 
Arlei Sander Damo: Bom, uma das características de seu trabalho é a negociação entre diferentes abordagens metodológicas, entre o macro e o microssociológico.

Christian Bromberger: O interessante da antropologia é de poder atuar em diversos níveis: o indivíduo, o pequeno grupo, o grande grupo e, em seguida, ver as significações num nível mais elevado, em relação a outras culturas ou outros sistemas socioculturais. É um pouco do que eu tentei fazer no Le match de football, encontrando indivíduos, pequenos grupos de torcedores, vendo em seguida a cidade através de seu futebol, e em seguida me perguntando o que pode bem querer dizer o fato de gostar de futebol, em relação a outras sociedades onde se gosta de outros jogos. O interessante da disciplina, segundo minha opinião, é a passagem de um nível a outro, para captar o conjunto das determinações que há por trás das práticas sociais e culturais. Seja em nível individual - por que Pierre ou Paul amam o futebol? - ou dos pequenos grupos, mas também da cidade e suas representações imaginárias. E depois ainda há o futebol em relação aos jogos astecas ou aos jogos da Austrália, etc. Tudo isso são os múltiplos níveis; é isso que faz a antropologia interessante. [...]

Ruben George Oliven: O que você pensa que está acontecendo neste momento na Europa. Eu não falo dos últimos atentados, mas das imigrações. Você pode fazer um exercício em antropologia sobre isso?

Christian Bromberger: O que me chocou em muitos países atravessados pelos imigrantes foi o estabelecimento de barreiras, de muros, de fios de arame farpado, etc. E de como a Alemanha, no começo ao menos, deu a ideia de que isso poderia compensar um déficit demográfico - o que não seria o caso da França. Ao mesmo tempo, o debate está despertando os populismos, sobretudo depois dos últimos episódios [referindo-se ao atentado à casa de espetáculos Bataclan, ocorrido em 13/11/2015]. Podemos fazer culturologia sobre isso? É difícil, mas podem-se notar claramente as reações em relação ao mundo árabe. Esses movimentos migratórios vão ser, com o tempo, aceitos? Eu estava na Letônia quando se falou das quotas. Na Letônia, eles deveriam receber 750 imigrantes, o que não é muito. Mas todo mundo só falava disso: "Oh, vamos receber 750..." Então eles me diziam: "Mas nós não falamos 
árabe", então eu lhes dizia: "Mas não cabe a vocês aprender o árabe [risos]!" É incrível, todos falavam disso! Na França, seriam aproximadamente 25.000, mas o que são 25.000 se há 36.000 comunas no país?

Eu moro em Aix-en-Provence, e temos uma prefeita que é de direita, da direita malvada. Ela disse: "Sim, nós aceitamos imigrantes, mas é preciso que eles sejam cristãos!" [risos]. Eu achei isso atroz. Como sou um pouco como Germaine Tillon, eu fui pesquisar e depois me manifestar, porque eu achava isso escandaloso. Mas no meio da manifestação chegaram algumas pessoas de extrema-direita dizendo "não queremos imigrantes", etc. Logo, há reações xenófobas. Porque há fenômenos de compaixão imediatista, numa Europa onde o desemprego é importante. Não creio que a Europa esteja pronta para uma mudança de população como essa. Pessoalmente, eu me pergunto o que faria se estivesse na Síria neste momento, com meus filhos: eu teria pedido para ser acolhido!

Ari Pedro Oro: Você brinca um pouco de profeta [...]. Seria uma tendência de haver um enfraquecimento dos símbolos nacionais, no sentido de como se veem hoje os franceses, os italianos, os ingleses, por exemplo? Porque as pessoas que chegam não têm mais essa relação profunda com o território, a cultura e tudo o mais...

Christian Bromberger: Houve um período de integração relativamente extraordinário, mas era um período economicamente próspero. Veja-se o caso do futebol. Os jogadores argelinos, nos anos 1950, falavam um francês perfeito. Hoje, ao contrário, a identificação à nação [de origem] não é mais um problema. Minha esposa é de origem italiana e se tornou professora de francês. Temos sempre na cabeça este modelo francês republicano. Mas ele está em vias de extinção na medida em que a situação econômica dos imigrantes é muito ruim, não há mais essa promoção pela integração que existia antes. Infelizmente, para o futuro, é um mau sinal. 


\section{Referências}

BROMBERGER, C. Le match de football: ethnologie d'une passion partisane à Marseille, Naples et Turin. Paris: Les Éditions de la Maison des sciences de l'homme, 1995.

BROMBERGER, C. Un autre Iran: un ethnologue au Gilân. Paris: Armand Colin, 2013.

LÉVI-STRAUSS, C. La pensée sauvage. Paris: Plon, 1962a.

LÉVI-STRAUSS, C. Le totémisme aujourd'hui. Paris: PUF, 1962b.

TILLION, G. Le harem et les cousins. Paris: Éditions du Seuil, 1966.

TILLION, G. Il était une fois l'ethnographie. Paris: Éditions du Seuil, 2000.

Recebido em: 31/05/2016

Aprovado em: 01/03/2017 